\title{
Financial Sector Development, Savings Mobilization and Poverty Reduction in Ghana
}

\author{
Peter Quartey*
}

December 2005

\begin{abstract}
The paper primarily investigates the interrelationship between financial sector development and poverty reduction in Ghana. This is done using time-series data from the World Development Indicators from 1970-2001. The main findings are, first, that even though financial sector development does not Granger-cause savings mobilization in Ghana, it induces poverty reduction; and second, that savings do Granger-cause poverty reduction in Ghana. Also, the effect of financial sector development on poverty reduction is positive but insignificant. This is due to the fact that financial intermediaries in Ghana have not adequately channelled savings to the pro-poor sectors of the economy because of government deficit financing, high default rate, lack of collateral and lack of proper business proposals. Another interesting finding is that there is a long-run cointegration relationship between financial sector development and poverty reduction.
\end{abstract}

Keywords: financial sector development, savings, poverty

JEL classification: E2, E21, G2

\section{Copyright (C) UNU-WIDER 2005}

* ISSER, University of Ghana, email: pquartey@ug.edu.gh, peter.quartey@btinternet.com

This study has been prepared within the UNU-WIDER project on Financial Sector Development for Growth and Poverty Reduction directed by Basudeb Guha-Khasnobis and George Mavrotas.

UNU-WIDER acknowledges the financial contributions to the research programme by the governments of Denmark (Royal Ministry of Foreign Affairs), Finland (Ministry for Foreign Affairs), Norway (Royal Ministry of Foreign Affairs), Sweden (Swedish International Development Cooperation Agency-Sida) and the United Kingdom (Department for International Development). 
The World Institute for Development Economics Research (WIDER) was established by the United Nations University (UNU) as its first research and training centre and started work in Helsinki, Finland in 1985. The Institute undertakes applied research and policy analysis on structural changes affecting the developing and transitional economies, provides a forum for the advocacy of policies leading to robust, equitable and environmentally sustainable growth, and promotes capacity strengthening and training in the field of economic and social policy making. Work is carried out by staff researchers and visiting scholars in Helsinki and through networks of collaborating scholars and institutions around the world.

www.wider.unu.edu

publications@wider.unu.edu

UNU World Institute for Development Economics Research (UNU-WIDER)

Katajanokanlaituri 6 B, 00160 Helsinki, Finland

Camera-ready typescript prepared by T:mi LHR Editorial and Secretarial Assistance

The views expressed in this publication are those of the author(s). Publication does not imply endorsement by the Institute or the United Nations University, nor by the programme/project sponsors, of any of the views expressed. 


\section{Introduction}

Domestic resources serve as a vital engine of growth and poverty reduction. However, the effective mobilization of domestic resources depends on an efficient and well developed financial market. The financial sector in Ghana has undergone change in terms of the number of institutions and services rendered, as a result of the financial sector liberalization programme pursued in the late 1980s that led to interest rate liberalization and the entrant of new players. The outcome of this liberalization policy is reflected in Ghana's financial development indicators: the M2/GDP ratio increased from 0.195 in 1996 to 0.32 in 2003. Similarly, over the same period the currency/M2 ratio declined from 0.41 to 0.29 .

Despite these developments, the level of mobilized domestic resources, savings included, has not been enough to stimulate private investment to propel the economy towards the desired level of growth. Savings as a percentage of GDP were 5.5 per cent in 1990, declined to 1.3 per cent in 1992 and continued to exhibit oscillatory trends until the year 2000 when a savings-to-GDP ratio of 3.5 per cent was recorded. On a positive note, the savings ratio has increased consistently thereafter and by 2002 reached 7.4 per cent (Figure 1).

However, private savings in Ghana remain low by African standard. Gross domestic savings as a percentage of GDP in Ghana are low compared to many African countries, and averaged 6.4 per cent between 1980 and 2001, while the corresponding figures were 37.4 per cent for Botswana, 21.4 per cent for Cameroon, 21.6 per cent for Nigeria, 13.9 per cent for Kenya and 7.3 per cent for Malawi (World Bank 2003). Thus, domestic resource mobilization has been relatively low, despite the innovations and developments within Ghana’s financial sector.

The development in the financial sector has also occurred during a period when poverty declined in Ghana, although the direction of causation has not been established. Between 1992 and 1999, the number of people considered to be poor dropped from 51 per cent to 40 per cent (GLSS 3 and 4). However, not all groups gained from this reduction in poverty. There were both winners and losers, the winners being the export farmers and the losers the foodcrop farmers, the majority of whom were women. In addition, people living in the urban areas of the northern savannah experienced an increase in their poverty level.

Poverty increased during the 1990s in the Upper East, Northern and Central regions, while significant reductions in poverty at the national level have been concentrated in four regions of Western, Greater Accra, Volta and Brong Ahafo. Other regions (Central, Northern, and Upper East) have experienced large increases in poverty between 1991 and 1999, while the remaining regions show little change. The Ghana Statistical Service (2003) results showing the distribution and intensity of poverty across regions are given in Figure 2. The proportion of the poor in the three northern regions remains high relative to other regions. About 68 per cent to 74 per cent of people in the three northern regions are either poor or very poor compared to between 18 per cent and 58 per cent in other regions. The level of poverty in Ghana when viewed in terms of occupation indicates that foodcrop farmers are the poorest (Figure 3). 
Figure 1

Savings GDP ratio 1990-2002

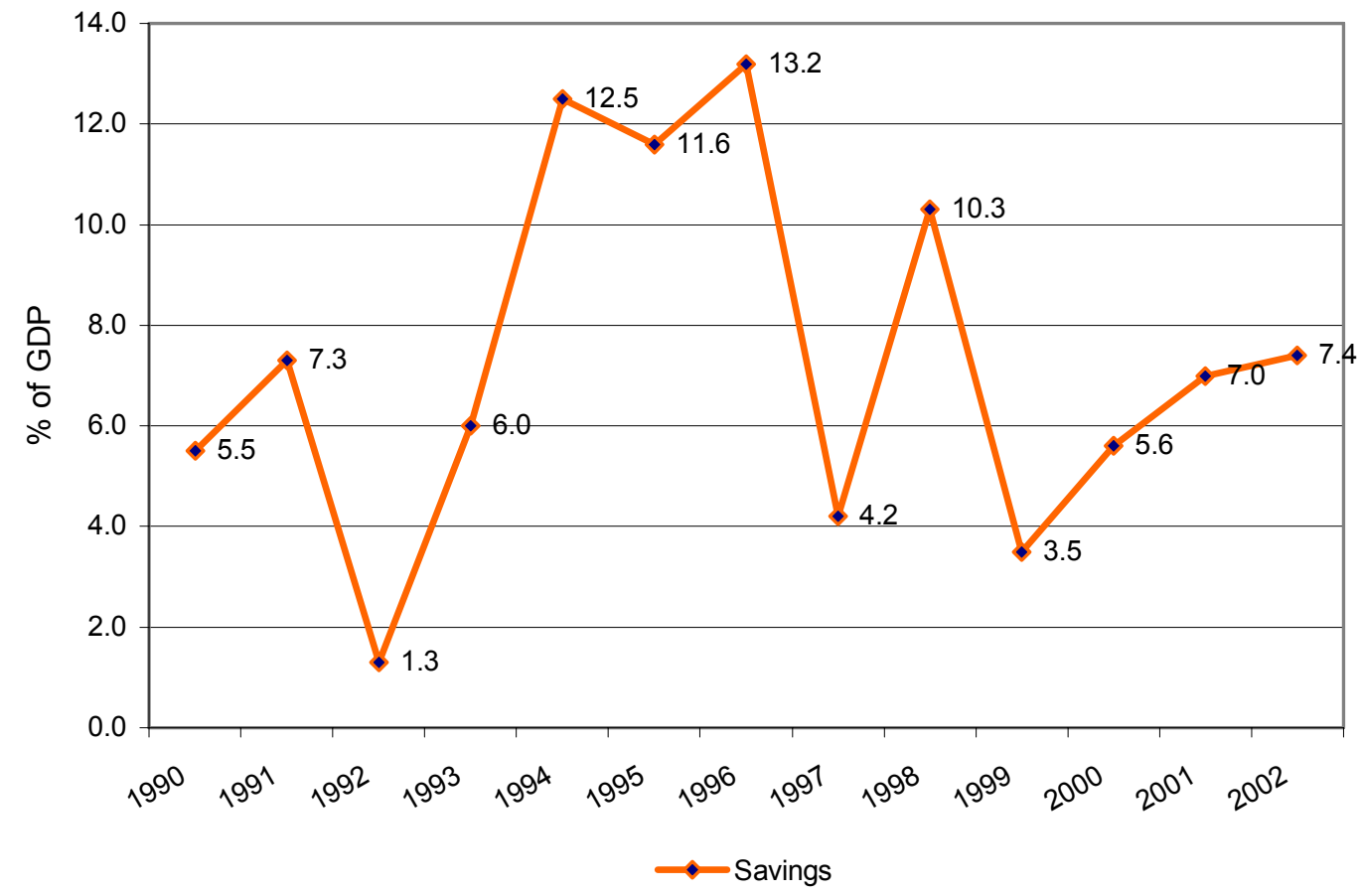

Source: World Bank (2004).

Figure 2

Regional distribution of households by poverty status

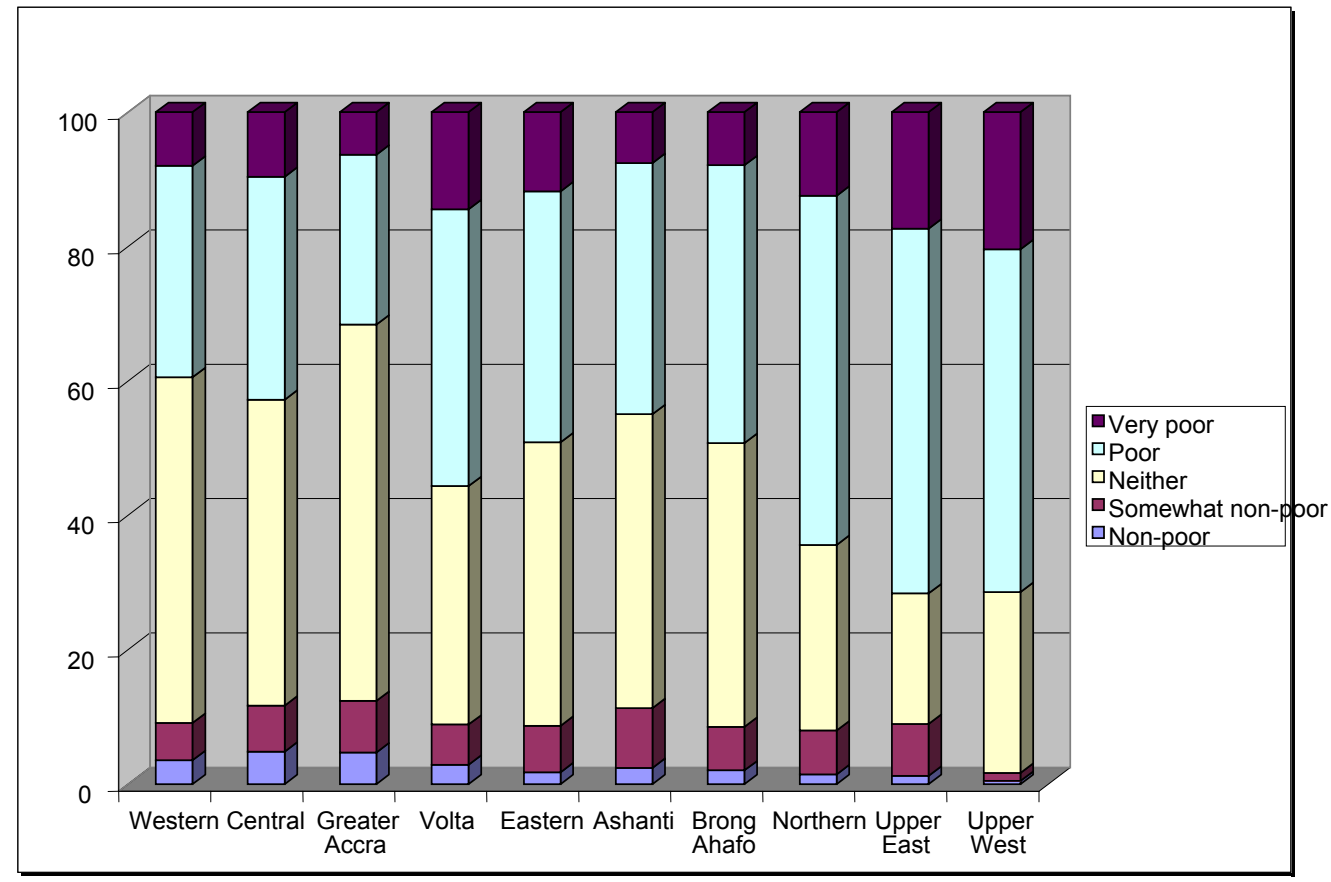

Source: Ghana Statistical Service (2003). 


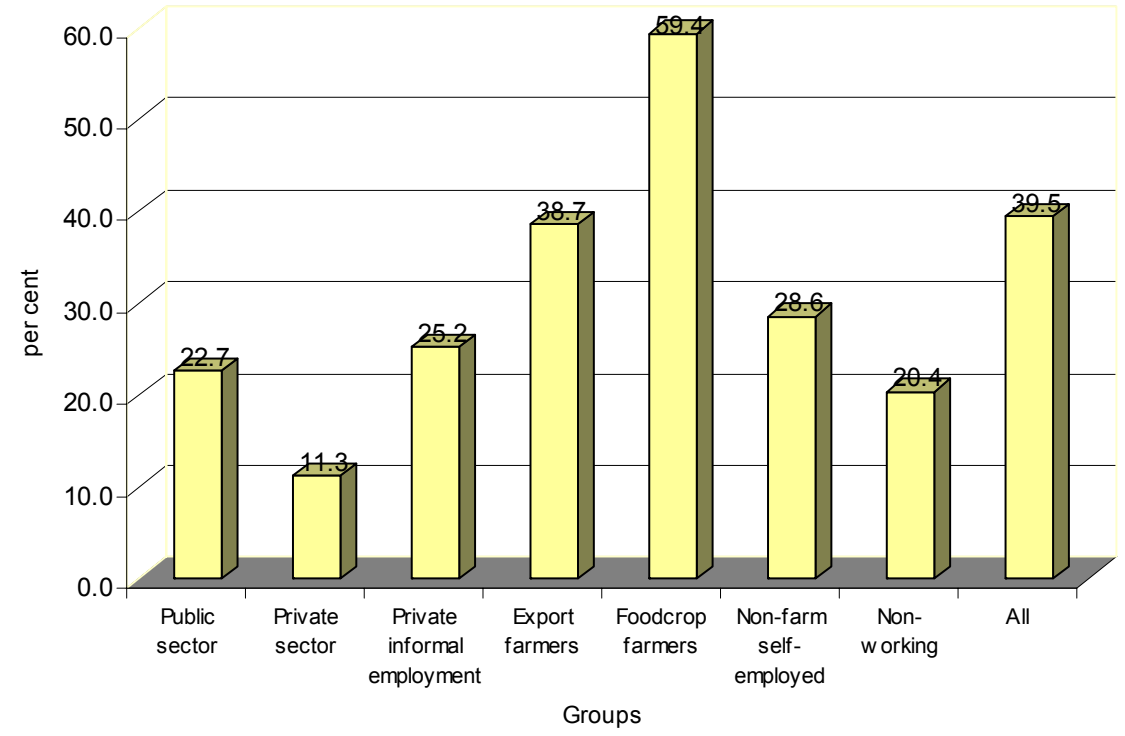

Source: Ghana Statistical Service (2000).

Thus far, there appears to be some development in Ghana's financial sector and aggregate poverty has declined, but the issue of whether the financial developments induced the poverty decline in Ghana remains a mystery. This problem is the focus of this paper. Section 2 traces the development of Ghana's financial sector from the 1990s. Section 3 examines the interrelationship between financial sector development, savings mobilization and poverty reduction. Section 4 presents the method of analysis, and section 5 analyses the data. The final section provides the concluding remarks.

\section{Developments in Ghana's financial sector}

As with most developing countries that have pursued economic and structural reforms, Ghana has undergone a process of financial sector restructuring and transformation as an integral part of a comprehensive financial sector liberalization programme. Ghana's financial sector liberalization programme began in the early $1990 \mathrm{~s}$ as part of a comprehensive macroeconomic adjustment programme with the support of the International Monetary Fund and the World Bank. This involved the restructuring of distressed banks and the cleaning up of non-performing bank assets to restore banks to profitability and viability.

The programme set the prices right, and initiated structural reforms to include fiscal and monetary operations as well as privatization, banks included. The reforms were a throwback to the history of severe distress and dysfunction in the banking system, illiquidity and insolvency, interest rate controls, and credit rationing punctuated by an event of vetting of accounts and the lingering effects on security deposits and confidentiality. In retrospect, the financial sector adjustment programme (FINSAP) was a successful reform agenda, though it remains a powerful reminder of the banking problems of the 1990s. 
The financial system that emerged after the reforms is relatively diversified in the range of services and increasingly offers innovative new products. While small- and mediumsized private enterprises depend extensively on self-financed capital investments, the economy is dominated primarily by bank-intermediated debt finance. The next stage and the thrust of financial market policy was therefore the development of a vibrant capital market as a vehicle for raising funds to support large amounts of equity finance and investment.

The reforms, liberalizing interest rates and bank credit by government, transformed the financial sector from a regime characterized by controls to a market-based one. The central bank also shifted gradually from a system of direct monetary controls to an indirect system that utilized market-based policy instruments. As part of the process, the Bank of Ghana rationalized the minimum reserve requirements for banks, introduced new financial instruments, and opened market operations for liquidity management. These policies were complemented with an improvement in the soundness of the banking system through a proper regulatory framework, the strengthening of bank supervision, and an upgrade in the efficiency and profitability of banks, including replacement of their non-performing assets (Quartey 1997).

As part of the process of full liberalization, the Bank of Ghana introduced in the first quarter of 2003 'universal banking', which allows banks to undertake commercial, development, investment or merchant banking without the need for separate licences. The practice also enables all banks capable of expanding into, or currently operating in banking areas other than those permitted by their licence or regulations, to undertake all types of banking business. This development, however, depends on the capital resources of the institution as it would, with the expected expansion, assume greater risk and therefore would need to be well resourced. There were further developments within Ghana's financial sector in 2003 which included the acquisition of 50+ per cent equity stakes in SSB Bank by Société Générale, the establishment of a local branch office by Citibank, Union Bank of Nigeria's acquisition of 20 per cent equity stake in Home Finance Company, a local mortgage institution, and the launch of a real time gross settlement system for high value transactions. These financial sector reforms have led to changes in Ghana's monetary indicators, which are discussed below.

\subsection{Financial deepening}

The reforms had significantly affected Ghana's financial development. The level of financial deepening as measured by $\mathrm{Cu} / \mathrm{M} 2+$, M1/GDP, M2/GDP and Cu/GDP improved between 1996 and 2003. Table 1 shows that M2+/GDP ratios increased from 0.195 in 1996 to 0.32 in 2003. Similarly, the currency/GDP ratio improved by 1.4 percentage points over the same period, while the currency ratio (Currency/M2+) improved by 12.0 percentage points for the same period. In Ghana, currency accounts for a greater proportion of transactions. Thus, the persistent decline in the currency ratio since the year 2000 signals an improvement in the financial depth of the economy. The decline in cash holdings in recent times can be attributed to the increase in the use of electronic cards within the economy. 
Table 1

Financial deepening, 1996-2003

\begin{tabular}{|c|c|c|c|c|c|c|c|c|}
\hline & $\begin{array}{c}\text { Nominal } \\
\mathrm{M} 2+\end{array}$ & $\begin{array}{l}\text { Nominal } \\
\text { M1 }\end{array}$ & $\begin{array}{l}\text { Currency } \\
\text { (Cu) }\end{array}$ & $\begin{array}{c}\text { Nominal } \\
\text { GDP }\end{array}$ & & & & \\
\hline Year-end & Cedis bn & Cedis bn & Cedis bn & Cedis bn & $\mathrm{M} 2+/ \mathrm{GDP}$ & M1/GDP & $\mathrm{Cu} / \mathrm{GDP}$ & $\mathrm{Cu} / \mathrm{M} 2+$ \\
\hline 1996 & $1,785.0$ & $1,215.1$ & 724.0 & $9,167.0$ & 0.195 & 0.133 & 0.079 & 0.41 \\
\hline 1997 & $2,506.0$ & $1,765.7$ & 981.8 & $13,863.0$ & 0.181 & 0.127 & 0.071 & 0.39 \\
\hline 1998 & $3,903.0$ & $2,070.0$ & 1,083.6 & $17,157.0$ & 0.227 & 0.121 & 0.063 & 0.28 \\
\hline 1999 & $4,896.5$ & $2,192.5$ & $1,272.4$ & $20,580.0$ & 0.238 & 0.107 & 0.062 & 0.26 \\
\hline 2000 & $7,248.1$ & $3,516.5$ & $2,635.5$ & $27,153.0$ & 0.267 & 0.130 & 0.097 & 0.36 \\
\hline 2001 & $10,248.0$ & $5,121.8$ & $3,089.9$ & $38,014.0$ & 0.270 & 0.135 & 0.081 & 0.30 \\
\hline 2002 & $15,368.1$ & $8,218.0$ & $4,671.6$ & $47,764.0$ & 0.322 & 0.172 & 0.098 & 0.30 \\
\hline 2003 & $20,875.4$ & $11,074.3$ & $6,039.3$ & $65,262.0$ & 0.320 & 0.170 & 0.093 & 0.29 \\
\hline
\end{tabular}

Source: Bank of Ghana Statistical Bulletins (various years).

\subsection{Trends in interest rates}

The prime rate has declined consistently from a high of 37.0 per cent in 1998 to 25.5 per cent in 2003 and further to 18.0 per cent in 2004. The Monetary Policy Committee (MPC) raised the prime rate from 24.5 per cent in December 2002 to 25.5 per cent in January 2003 to reflect the generated inflationary pressures following the monetary expansion that was undertaken during the last quarter of 2002. The rate was reduced in February to its December 2002 level, only to be raised steadily to 27.5 per cent by April 2003 when petroleum price adjustments caused inflation to reach 30 per cent. The prime rate was maintained at this level until July when the inflationary pressures receded. The MPC gradually reduced the rate to 21.5 per cent by year-end 2003 and it was 18.8 per cent by the end of 2004 .

Table 2

Interest rates, 1998-2003

\begin{tabular}{|c|c|c|c|c|c|c|}
\hline & \multicolumn{6}{|c|}{ Averages (\% per annum) } \\
\hline & 1998 & 1999 & 2000 & 2001 & 2002 & 2003 \\
\hline \multicolumn{7}{|l|}{ Central bank } \\
\hline Bank rate/prime rate* & 37.00 & 27.00 & 27.00 & 27.00 & 24.50 & 25.50 \\
\hline Treasury bill discount rate (91days) & 26.75 & 31.49 & 38.00 & 27.65 & 23.68 & 26.36 \\
\hline Interest rate equivalent & 28.67 & 34.18 & 41.99 & 29.70 & 25.16 & 28.27 \\
\hline \multicolumn{7}{|l|}{ Commercial banks } \\
\hline \multicolumn{7}{|l|}{ a. Deposit rates } \\
\hline Demand deposits & 4.70 & 8.50 & 16.75 & 13.50 & 8.00 & 8.50 \\
\hline Savings deposits & 16.50 & 10.50 & 18.00 & 14.50 & 11.13 & 11.09 \\
\hline Time deposits (3 months) & 29.50 & 21.75 & 33.50 & 23.25 & 16.22 & 14.28 \\
\hline Certificates of deposit & 25.25 & 18.75 & 33.75 & 18.00 & 14.56 & 15.79 \\
\hline Call money & 23.00 & na & 28.00 & 17.00 & 12.17 & 12.52 \\
\hline Others & 22.27 & 17.44 & 24.80 & 18.33 & 12.83 & 13.42 \\
\hline b. Lending rates & 38.50 & 36.50 & 47.00 & 43.75 & 36.36 & 34.95 \\
\hline
\end{tabular}

Note: * The prime rate was introduced at the end of March 2002.

Source: $\quad$ Bank of Ghana Statistical Bulletins (2004). 
Meanwhile, the savings rate has increased marginally over the same period: from 16.5 per cent in 1998 to 18 per cent in 2000 but declining thereafter to 11.09 per cent in 2003. Similarly, the lending rates of banks have also responded marginally to the decline in the bank's prime rate. The lending rate was 38.5 per cent in 1998, rose to 47 per cent in 2000 but declined to 34.95 per cent in 2003. Obviously, such a huge margin between the lending and savings rate does not augur well for financial intermediation and this is reflected in the low savings rate in the economy.

In contrary, the money market rates were more flexible to interest rate movements compared to lending and borrowing rates. Between 2002 and 2004, the rates on money market instruments and the inter-bank weighted average rates were the most responsive to movements in the prime rate during the period. In response to the downward trend in the prime rate during the second half of 2003, the 91-day bill rate and the weighted inter-bank average rate declined by the end of 2003 by 16.61 and 9.55 percentage points, respectively.

\subsection{Domestic resource mobilization}

The level of private savings in Ghana is low by African standard and in recent times there appears to be a shift from savings and time deposits towards money market instruments (ISSER 2004). The share of money market instruments increased consistently from 48.9 per cent in 1995 to 57.7 per cent in 2001 and then to 62.7 per cent in 2003, while the share of savings deposits in total private savings declined steadily from 27.1 per cent in 2001 to 23.0 per cent in 2003 (Table 3). However, although time deposits declined from 15.8 per cent in 2001 to 13.1 per cent in 2002, these increased to 14.3 per cent in 2003. Thus, money market instruments remain a dominant component of total private savings, accounting for 62.7 per cent of total private savings in 2003, while savings deposits and time deposits accounted for 23.0 per cent and 14.3 per cent of total private savings, respectively (Table 3). Also, between 2001 and 2003, preferences shifted from short-term instruments towards long-term instruments.

The year 2003 also recorded an increase from Cedis 3,332.7 billion in 2002 to Cedis 4,786.0 billion in the nominal values of private savings and an increase of

Table 3

Private savings with formal financial institutions, 1995-2003 (\%)

\begin{tabular}{lcccc}
\hline Year & Money market instruments & Savings deposits & Time deposits & Total \\
\hline 1995 & 48.9 & 40.2 & 10.9 & 100 \\
1996 & 51.0 & 39.8 & 9.2 & 100 \\
1997 & 52.0 & 30.7 & 17.3 & 100 \\
1998 & 55.6 & 25.3 & 19.1 & 100 \\
1999 & 51.5 & 19.9 & 28.6 & 100 \\
2000 & 61.2 & 23.8 & 15.0 & 100 \\
2001 & 57.7 & 27.1 & 15.8 & 100 \\
2002 & 58.1 & 28.8 & 13.1 & 100 \\
2003 & 62.7 & 23.0 & 14.3 & 100 \\
\hline
\end{tabular}

Source: Calculated from the Bank of Ghana Statistical Bulletin (February 2004). 
43.6 per cent for time deposits as compared to the 32.5 per cent growth rate recorded between 2001 and 2002. Foreign currency deposits with domestic money banks (DMBs) rose from Cedis 3553.3 billion to Cedis 4576 billion, representing a 28.8 per cent increase compared to an increase of 49.7 per cent recorded in 2002 (Table 3). This partly accounts for the relatively low changes in 2003 in money supply growth, inflation and the exchange rate as compared to the preceding year.

It is worth emphasizing that most savings, especially by the relatively poor, are held in the form of real assets. Aryeetey (2005) argues that this equilibrium portfolio allocation results from both the poor performance of financial assets and the strong desire for owning the real assets used directly in production. These, in turn, are both consequences (in large part) of information asymmetries. The poor performance of financial assets is not particularly surprising, because financial 'saving' is affected by precisely the same information and enforcement difficulties as 'lending'. As a result, much of the financial savings that does occur is held within close social groups in order to circumvent the moral hazard and adverse selection problems associated with entrusting assets to strangers.

\section{Financial sector development and poverty reduction}

\subsection{Financial sector development and savings mobilization}

Literature clearly suggests a strong positive relationship between financial sector development and savings mobilization. In the early works of McKinnon (1973) and Shaw (1973), they argue that the liberalization of interest rates would end financial repression and cause financial deepening due to the resulting increased efficiency of the intermediation process, and the effects of higher interest rates on savings. The difference between the hypotheses of these two authors is in the transmission mechanisms through which they believe this process would occur. Similarly, Mavrotas and Santillana (1999) present the theoretical links between financial sector liberalization and savings mobilization based on the life-cycle or permanent income theory of consumption. They argue that financial liberalization increases competition between providers of financial intermediation, thereby eliminating the constraint on borrowing. This means that the young can now borrow in order to attain their optimal lifetime consumption path.

Empirical studies on the linkage between financial liberalization and the consumption/savings decision of individuals can be classified largely into two groups, depending on whether the focus is on consumption or savings. The group of studies that focuses on consumption usually extends the Euler equation framework of Hall (1978) and Campbell and Mankiw (1989) and examines whether consumption growth responds to various measures of financial liberalization. These studies typically find that financial liberalization increases current consumption growth by relaxing credit constraints (see, for example, Ludvigson 1996; King 1986; de Brouwer 1996; and Bacchetta and Gerlach 1997). However, the results from these studies are not directly related with the issue of financial liberalization and saving.

According to the standard theory, the interest rate is positively correlated with consumption growth (permanent income hypothesis) but has an ambiguous impact on 
saving. Similarly, financial liberalization may affect consumption growth but with no clear effect on saving. However, the results of some studies suggest that financial liberalization actually reduces the quantity of savings (Muellbauer and Murphy 1993; de Melo and Tybout 1986; Jappelli and Pagano 1994; Ostry and Levy 1995; Bandiera et al. 2000). On the contrary, Bandiera et al. (1998) using a principal components analysis find that the effects of financial liberalization on savings differ across countries; there is no evidence of significant and sizeable interest rate effects. Overall, there is no firm evidence that liberalization increases savings; often it will reduce it.

Although financial liberalization can enhance the efficiency with which saved resources are channelled into productive use, the effect on the quantity of savings is theoretically ambiguous (Bandiera et al. 2000). The mechanisms at work here include both long-term and short-term effects. Having settled down, a competitive liberalized financial system will typically be characterized by improved savings opportunities, including higher deposit interest rates, a wider range of savings media with improved risk-return characteristics and, in many cases, more banks and bank branches, as well as other financial intermediaries. Bank lending rates will typically be higher for those borrowers who had privileged access in the restricted regime, but access to borrowing should be wider. These long-term effects of liberalization on aggregate private savings will be felt through changes in the rates of return and in the degree of credit restrictions. Moreover, financial liberalization can have a favourable effect on the allocation of resources which will generate increases in income that will, in turn, increase savings.

The process of financial liberalization also unleashes a series of short-run effects. In particular, not only can the process of domestic portfolio adjustment lead to transitory changes in the volume of domestic savings, but (especially when combined with liberalization of the foreign exchange market) it may also induce large capital inflows and such inflows, if not sterilized, can result in a credit boom leading to real income surges. These, in turn, have a direct but transitory effect on the volume of savings. Therefore, in modelling the effect of financial liberalization on saving, consideration would have to be given to these short-run effects, as well as the long-run effects. It is also important to recognize that some of the overall effects can come through the effect of income on savings.

\subsection{Savings mobilization and growth}

Some studies have also examined the relationship between domestic resource mobilization including private savings and economic growth. The Harrod Domar model predicts a strong positive relationship between economic savings and growth. Similarly, in the Solow-Swan model, a change in the savings rate changes the economy's balanced growth path and hence per capita output in the steady state, but it does not affect the growth rate of output per worker on the balanced growth path. Only an exogenous technological change will result in a further increase in output per worker in the steady state. By contrast in the Romer growth model, technology is endogenized and therefore an increase in the savings rate not only raises the per capita output in steady state but also increases the growth rate of per capita output.

Mavrotas and Santillana (1999) support the view that higher savings raise the growth of GDP by increasing capital accumulation. They note that the investment growth link has been challenged by a number of studies which argue that the co-movement of 
investment ratios and growth rates may be mainly the result of a third crucial factor, namely technological innovation, which drives both output expansion and capital accumulation. More precisely, they indicate that recent empirical studies cast serious doubts on the hypothesized positive impact of investment on growth. Mavrotas and Santillana provide robust empirical evidence according to which, even though a causal link seems to be apparent, the direction of causation runs from growth to investment and not vice versa, as pointed out by King and Levine (1994) and Benhabib and Jovanovic (1991) and much later by Blomstrom, Lipsey and Zejan (1996). However, the authors explain that the intrinsic endogeneity of the two makes the assessment of the direction of causation extremely difficult.

Some authors have attempted to deal with the endogeneity problem of savings and growth through mechanisms such as the use of instrumental variables techniques and causality tests. Carroll and Weil (1993) use household level data to deal with this issue and conclude that there is evidence suggesting that growth indeed affects private savings positively. Cardenas and Escobar (1998) also examine the question of causation for Colombia by using a first-order vector autoregression of the growth rate and the savings rate for the 1925-94 period. They find that changes in national savings and changes in investment are perfectly correlated and that savings Granger-cause growth. Similarly, an earlier work by Edwards (1996) finds that the coefficient on the rate of growth in per capita GDP is significantly positive in a private savings regression, and seems to provide some support to the hypothesis that there is a vicious circle in operation.

Mavrotas and Kelly (2001) use a methodology proposed by Toda and Yamamoto (1995) to test for causality between growth and savings in order to avoid the problems and possible misleading inferences associated with the asymptotic nature of Granger causality testing in time-series studies. The relationship between gross domestic product, gross domestic savings and private savings is examined for India and Sri Lanka, and they find no causality between GDP growth and private savings in India, but there appears to be a bi-directional causality between private savings and growth in Sri Lanka. These authors conclude that the existing evidence on the subject should be treated with caution, given the inappropriateness of the econometric methodology adopted in most of the previous empirical studies using time-series data.

In a related study, Kelly and Mavrotas (2003) use panel integration and cointegration tests for a dynamic heterogeneous panel of 17 African countries to examine the impact of financial sector development on private savings. They use three different measures of financial sector development to capture the variety of channels through which financial structure can affect the domestic economy. The empirical results obtained vary considerably among the countries in the panel, thus highlighting the importance of using different measures of financial sector development rather than a single indicator. The evidence is rather inconclusive, although in most of the countries in the sample a positive relationship between financial sector development and private savings seems to hold. Their empirical analysis also suggests that a change in government savings is offset by an opposite change in private savings in most of the countries in the panel, thus confirming the Ricardian equivalence hypothesis. Liquidity constraints do not seem to play a vital role in most of the African countries in the group, since the relevant coefficient is negative and significant in only a small group of countries. 
Similarly, a study by Anoruo and Ahmad (2001) utilizes cointegration and the vector error-correction modelling technique (VECM) to explore the causal relationship between economic growth and growth rate of domestic savings for Congo, Côte d'Ivoire, Ghana, Kenya, South Africa, and Zambia. Specifically, three analyses are undertaken; first, the time-series properties of economic growth and domestic savings were ascertained with the help of the augmented Dickey-Fuller unit root procedure. Second, the long-run relationship between economic growth and growth rate of domestic savings was examined in the context of the Johansen and Juselius (1990) framework. Finally, a Granger-causality test was undertaken to determine the direction of causality between economic growth and growth rate of domestic savings. The results indicate one order of integration for each of the series. The results of the cointegration tests suggest that there is a long-run relationship between economic growth and the growth rate of savings. Also, contrary to conventional wisdom, economic growth prima facie causes growth rate of domestic savings for most of the countries in their sample.

\subsection{Financial sector development and economic growth}

Other studies have also examined the link between financial sector development, economic growth and poverty reduction in order to identify clearly the channels through which financial sector development can influence economic growth. Theorists can be subdivided into two broad schools of thought: (i) the structuralists, and (ii) the repressionists. The structuralists contend that the quantity and composition of financial variables induce economic growth by directly increasing savings in the form of financial assets, thus encouraging the capital formation that leads to economic growth and consequently poverty reduction.

The financial repressionists, led by McKinnon (1973) and Shaw (1973)—often referred to as the 'McKinnon-Shaw' hypothesis - contend that financial liberalization in the form of an appropriate rate of return on real cash balances is a vehicle for promoting economic growth. The essential tenet of this hypothesis is that a low or negative real interest rate will discourage savings. This will reduce the availability of loanable funds for investment which, in turn, will lower the rate of economic growth. Thus, the McKinnon-Shaw model posits that a more liberalized financial system will increase competition, increase interest rates and induce an increase in savings and investment and consequently promote economic growth. Empirical studies have also established the relationship between financial sector development and economic growth. Jung (1986) finds a bi-directional causality between financial and real variables in post-war data for 56 countries, 19 of which are developed industrial economies. Demetriades and Hussein (1996) conduct causality tests and find little evidence that financial sector development causes economic growth. They note that causality patterns vary across countries. On the other hand, Wachtel and Rousseau (1995) find that financial sector development Granger-causes economic growth.

\subsection{Financial sector development and poverty reduction}

Few studies have attempted to establish the relationship between financial sector development and poverty reduction. The interaction between financial development and poverty can be examined by first considering the contribution that financial development makes to the growth performance of the economy. This, in turn, has 
implications for changes in the poverty level within the economy. Deininger and Squire (1996) and later Dollar and Kraay (2001) argue that growth has been beneficial for the poor. Using data on the income of the lowest quintiles, they show empirically that the poor have benefited from growth at least as much as the other quintiles. Dollar and Kraay's empirical results suggest that 'good' macroeconomic policies, openness and globalization have a positive, direct impact on the income of the poor.

Similarly, Jalilian and Kirkpatrick (2001) examine the link between financial development and poverty reduction by using data for a sample of 26 countries, including 18 developing countries. They use bank deposit money assets, and net foreign assets as measures of financial development. Their results suggest that a 1 per cent change in financial development raises growth in the incomes of the poor in developing countries by almost 0.4 per cent.

Financial development can also have an indirect impact on the living standards of the poor through its support of economic growth (World Bank 2001: 6). The relationship between growth and poverty has been the focus of considerable attention in recent years (Squire 1999; World Bank 2001; Ravallion 2001). A World Bank study (2001b: 52) explains that any given growth scenario can generate different poverty outcomes-for a given rate of growth, the extent of poverty reduction depends on how the distribution of income changes with changes in growth, and on initial inequalities in income, assets and access to opportunities to allow the poor to share in growth. Equi-proportional growth leaves income distribution intact, whereas by improving the position of some at the lower scale of distribution, it reduces poverty. Pro-poor growth, however, will by definition improve the status of the poor and affect income distribution.

Studies have shown that financial sector development can lead to poverty reduction and can also affect inequality. For instance, Goudie and Ladd (1999) and McKay (2002) argue that although growth will benefit the non-poor in the society, at the same time it will improve income distribution. It is obvious, therefore, that aggregate growth may have different relationships to poverty. Beck, Demirgüç-Kunt and Levine (2004) use data on 52 developing and developed countries over the period 1960-99 to assess whether there is a direct relationship between financial development (measured by credit to private sector ratio) and changes in income distribution. They find that the income of the poorest 20 per cent of the population grows faster than the average GDP per capita in countries with higher financial development, and that income inequality falls. They also find that financial development contributes to reductions in infant mortality. Similarly, Honohan (2004) finds that financial development (measured by private credit to GDP ratio) is negatively associated with headcount poverty, with a coefficient suggesting that a 10 percentage point increase in the ratio of private credit to GDP should (even at the same mean income level) reduce poverty ratios by 2.5 to 3 percentage points.

Some studies have examined the relationship between financial development and the distribution of income, about which there are competing theories. For example, Greenwood and Jovanovich (1990) argue that there is an inverted U-shaped relationship between income inequality and financial development, that is, financial development leads to greater inequality to begin with, but which falls back again as financial development continues. This theory is based on the idea that financial intermediaries provide savers with higher returns and lower risks, but that poor individuals initially cannot afford to make use of these financial intermediaries, which results in growing 
inequality. It is assumed, however, that more and more poor people will be able to afford to use these intermediaries over time, offsetting the initial increase in inequality.

Banerjee and Newman (1993) and Galor and Zeira (1993) argue that imperfections in financial markets create hurdles to borrowing funds for income-enhancing investments. It is only the rich who are able to overcome these hurdles and therefore they serve to perpetuate the initial distribution of wealth. Financial development overcomes these imperfections and therefore reduces income inequality (i.e., there is a negative relationship between the two).

Clarke, $\mathrm{Xu}$ and Fou (2002) empirically investigate these alternative theories on the relationship between financial development and income inequality with data from 91 countries between 1960 and 1995. As measures of financial development, they use credit to the private sector by financial intermediaries, and claims on the non-financial domestic sector by banks. Their findings support the theory that there is a negative relationship between financial development and income inequality rather than an inverted U-shaped relationship. They note that financial development reduces inequality, even when there are initially low levels of financial development. However, they also find that the beneficial impact of financial development on income inequality is smaller in countries with larger modern (non-agricultural) sectors.

These same authors (Clarke, $\mathrm{Xu}$ and Fou 2002) also provide some support for the Kuznets based theory which suggests that financial development facilitates more migration from the low-income but more egalitarian agricultural sector to the higherincome but unequal modern (industrial and services) sector. Thus, financial sector development increases inequality, although it still reduces income inequality as long as the modern sector accounts for less than 99.6 per cent of GDP (which was true of almost all countries in the sample). For the average country in the sample, they estimate that a 1 per cent increase in private credit reduces inequality by 0.3 per cent.

Evidence on the relationship between financial development and inequality is mixed, that is, neither the theory nor the evidence is conclusive on the impact of financial development on inequality. In conclusion, there is strong evidence from the literature that financial sector development can lead to poverty reduction. The financial system in Ghana has witnessed considerable development, including interest rate liberation and the emergence of new products and institutions. However, there has been an empirical study using multivariate causality tests to establish and explain the relationship between financial sector development, savings mobilization and poverty reduction in Ghana. This raises the following issues:

i) Why has the financial sector development not stimulated domestic resource mobilization?

ii) Have financial intermediaries intermediated savings into the pro-poor sectors of the economy?

iii) Has the formal financial sector responded to interest rate cuts by the central bank to reduce the cost of credit to the pro-poor sector of the economy, particularly small and medium enterprises?

These issues will be the principal focus of investigation by the proposed study. 
The study uses both descriptive and analytical statistical methods to examine the interrelationship between financial sector development, domestic resource mobilization and poverty reduction. It will specifically investigate the following issues:

i) Explore, with a series of causality tests, the direction of causality between (a) financial sector development and domestic resource mobilization; (b) financial sector development and poverty reduction; and (c) domestic resource mobilization and poverty reduction. These causal relationships will be examined;

ii) Investigate whether there is a long-run relationship between financial sector development and poverty reduction in Ghana; and

iii) Suggest ways in which the financial sector development in Ghana can accelerate poverty reduction.

\section{Methods of analysis}

The study adopts the descriptive statistical analysis approach using frequency distribution of indicators of financial sector development, domestic revenue mobilization and poverty. It exploits the causality between (i) financial sector development and domestic resource mobilization; (ii) financial sector development and poverty reduction, and (iii) domestic resource mobilization and poverty reduction. The causal relationships are examined with the help of a Granger-causality procedure. To determine whether there is a long-run relationship among financial sector development, domestic resource mobilization and poverty reduction, the Johansen cointegration procedure is used (Johansen and Juselius 1990; Johansen 1991).

\subsection{Definition of variables and data sources}

The detection of causal relationships within a set of variables is one of the objectives of empirical research. A degree of correlation between financial sector development, domestic resource mobilization and poverty reduction does not necessarily mean the existence of a causal relationship among them; it may simply be attributable to the common association of a third variable. Accordingly, Granger formulated a procedure for detecting a causal relationship among the variables applied in section 5. Having established the direction of causality, an empirical model of the determinants of financial sector development will be estimated. The model is specified as:

$$
Y i=\beta_{1}+\beta_{i} X_{i}+e_{i}
$$

where $Y i$ is financial sector development and $X s$ is a vector of explanatory variables including income measures of poverty. The variables used in the analysis are defined in Table 4.

The study relies heavily on the data obtained from The Bank of Ghana Statistical Bulletins and the World Bank's World Development Indicators (2003). Annual data from 1970 to 2002 are used. 
Table 4

Definition of variables

\begin{tabular}{ll}
\hline Variable & Definition \\
\hline GDSGDP & Gross domestic savings measured as a percentage of GDP \\
DCRPGDP & Domestic credit to the private sector as a percentage of GDP \\
PCONS & Per capita consumption \\
M2GDP & M2 as a percentage of GDP \\
EX & Exchange rate \\
POPG & Population growth rate \\
TOT & Terms of trade \\
\hline
\end{tabular}

\section{$5 \quad$ Findings}

\subsection{Unit root test}

We report the data properties by examining the unit root properties of the variables in Table 5. The equation estimated for the augmented Dickey-Fuller (ADF) test is stated as follows:

$$
\Delta X_{t}=\phi_{0}+\beta_{t} X_{t-1}+\sum_{i=1}^{n} \theta_{i} \Delta X_{t-1}+\varepsilon_{t}
$$

where $\Delta$ is the first difference operator, $t$ is the time trend, $\varepsilon$ is the stationary random error and $n$ is the maximum lag length. The null hypothesis is that the series contains a unit root which implies that $\beta_{1}=0$. The null hypothesis is rejected if $\beta_{1}$ is negative and statistically significant.

Table 5

The augmented Dickey-Fuller (ADF) unit root test

\begin{tabular}{lllll}
\hline Variable & t-adf & lag 1 & Variable & t-adf \\
\hline M2GDP & -1.8518 & 3 & $\Delta$ M2GDP & -1.6206 \\
M2GDP & -0.92123 & 2 & $\Delta$ M2GDP & -1.7201 \\
M2GDP & -1.0185 & 1 & $\Delta$ M2GDP & $-3.7202^{* *}$ \\
M2GDP & -1.0129 & 0 & $\Delta$ M2GDP & $-4.9813^{* *}$ \\
GDSGDP & -2.7687 & 3 & $\Delta$ GDSGDP & $-4.1902^{* *}$ \\
GDSGDP & -2.2767 & 2 & $\Delta$ GDSGDP & -2.6635 \\
GDSGDP & -2.0322 & 1 & $\Delta$ GDSGDP & $-3.7737^{* *}$ \\
GDSGDP & $-3.7015^{*}$ & 0 & $\Delta$ GDSGDP & $-9.8038^{* *}$ \\
PCONS & $-3.5456^{*}$ & 3 & $\Delta$ PCONS & -2.9422 \\
PCONS & $-3.6002^{*}$ & 2 & $\Delta$ PCONS & $-3.9141^{* *}$ \\
PCONS & $-3.9469^{* *}$ & 1 & $\Delta$ PCONS & $-4.7750^{* *}$ \\
PCONS & $-4.0135^{* *}$ & 0 & $\Delta$ PCONS & $-5.3824^{* *}$ \\
DCRPGDP & 0.70164 & 3 & $\Delta$ DCRPGDP & -0.93909 \\
DCRPGDP & 0.88071 & 2 & $\Delta$ DCRPGDP & -1.5896 \\
DCRPGDP & 0.96086 & 1 & $\Delta$ DCRPGDP & -2.3614 \\
DCRPGDP & 1.9869 & 0 & $\Delta$ DCRPGDP & $-3.0410^{*}$ \\
\hline
\end{tabular}

Notes: $\quad$ * Lag length selected using $\mathrm{T}^{1 /}$

Unit-root tests in levels 4 to 31 ;

Critical values: $5 \%=-2.971 ; 1 \%=-3.685$; constant included;

Unit-root tests in 1st difference $(\Delta) 5$ to 31 ;

Critical values: $5 \%=-2.975 ; 1 \%=-3.696$; constant included. 
In all cases except for gross domestic savings measured as a percentage of GDP (GDSGDP), which is stationary in levels at zero lag length, the financial sector development indicators, M2/GDP and domestic credit to the private sector measured as a percentage of GDP (DCRPGDP) have unit roots. Per capita consumption (PCONS) also follows a random walk. All the variables that are stationary after first difference are integrated of first order I (1). These tests are complemented with graphical analysis (Appendix Figures 1 and 2) which shows that the variables become stationary after the first difference.

\subsection{Causality test}

We undertake causality test to establish the link between financial development, domestic savings and per capita consumption (a measure of poverty) and these results are reported in Table 6. The null hypothesis of no causal relationships between gross domestic savings measured as a percentage of GDP (GDSGDP) and financial development measured as domestic credit to the private sector as a percentage of GDP (DCRPGDP) is accepted. In Ghana, the two variables do not predict each other. Credit to the private sector (DCRGDD) strongly predicts PCONS with a probability of 1 per cent. The key issue that emerges from Table 6 is that financial sector development induces poverty reduction.

Table 6

Granger causality test

Sample: 19702001

Lags: 3

\begin{tabular}{llcc}
\hline Null hypothesis & Obs. & F-Statistics & Probability \\
\hline DDCRPGDP does not Granger-cause DGDSGDP & 27 & 0.79617 & 0.51041 \\
DGDSGDP does not Granger-cause DDCRPGDP & & 0.76527 & 0.52683 \\
DM2GDP does not Granger-cause DGDSGDP & 28 & 0.07838 & 0.97101 \\
DGDSGDP does not Granger-cause DM2GDP & & 0.31662 & 0.81320 \\
DPCONS does not Granger-cause DGDSGDP & 28 & 0.06626 & 0.97719 \\
DGDSGDP does not Granger-cause DPCONS & & 1.54357 & 0.23270 \\
DM2GDP does not Granger-cause DDCRPGDP & 27 & 0.07602 & 0.97221 \\
DDCRPGDP does not Granger-cause DM2GDP & 27 & 0.47453 & 0.70350 \\
DPCONS does not Granger-cause DDCRPGDP & & 6.65407 & $0.00269 * * 2$ \\
DDCRPGDP does not Granger-cause DPCONS & 28 & 1.62635 & 0.21338 \\
DPCONS does not Granger-cause DM2GDP & & 1.54803 & 0.23162 \\
DM2GDP does not Granger-cause DPCONS & & & 0.38005 \\
\hline
\end{tabular}

Notes: $\quad{ }^{* * *}$ Significant at $1 \% ;{ }^{* *}$ significant at $5 \% ;{ }^{*}$ significant at $10 \%$.

\subsection{Financial sector development and poverty reduction}

Having established the causal relationship between financial sector development and poverty, we proceed with the Johansen (1982) procedure to test for the long-run relationship between financial sector development and poverty reduction in Ghana. The findings as presented in Table 7 reject the null hypothesis of no cointegration at 1 per cent level of significance in favour of two cointegration vectors, at most. The long-run 
relationship between financial development, domestic savings and poverty in Ghana has thus been established. The fact that there is a long-run equilibrium relationship among the three series confirms the existence of causality at least in one direction. This goes to confirm the earlier estimates from the Granger causality test reported in Table 6.

\subsection{Johansen cointegration test}

Table 7 shows the eigenvalues, likelihood ratio is trace test statistics adjusted for degrees of freedom. The result shows that we have two significant vectors. It should be noted that in a system of $\mathrm{N}$ variables, we should expect to generate or identify $\mathrm{N}-1$ cointegrating vectors. The method used here helps us to get the most significant vectors.

The cointegration test includes financial development indicators (DCRPGDP or M2GDP), domestic savings (GDSGDP) and per capita consumption (PCONS).

The cointegrating vector is not identified unless we impose some arbitrary normalization. The normalized cointegrating relation assuming two cointegrating relation $r=2$ is given in Table 8 . The vectors are identified jointly and normalized with DCRPGDP and GDSGDP consistent with the objectives of the study. The first vector is normalized with DCRPGDP. We see that the coefficients of this vector for DCRPGDP are consistent with theory.

Table 7

Johansen cointegration test

\begin{tabular}{lcccc}
\hline Hypothesized no. of CE(s) & Eigenvalue & Trace statistic & 5\% Critical value & 1\% Critical value \\
\hline None ** & 0.723 & 50.107 & 29.68 & 35.65 \\
At most 1 * & 0.434 & 15.443 & 15.41 & 20.04 \\
At most 2 & 0.001 & 0.029 & 3.76 & 6.65 \\
\hline
\end{tabular}

Note: $\quad{ }^{*}\left({ }^{* *}\right)$ denotes rejection of the hypothesis at $5 \%(1 \%)$ significance level;

Trace test indicates 2 cointegrating equation(s) at $5 \%$ significance level.

Table 8

Normalized cointegration relationship

\begin{tabular}{llll}
\hline DCRPGDP & GDSGDP & PCONS \\
\hline
\end{tabular}

Normalized cointegrating coefficients: 1 cointegrating equation(s)

\begin{tabular}{lccc}
\hline 1.000000 & -3.737735 & 0.304064 & -67.63952 \\
& $(2.38482)$ & $(0.23273)$ & \\
Loglikelihood & -198.6376 & &
\end{tabular}

Normalized cointegrating coefficients: 2 cointegrating equation(s)

\begin{tabular}{lccc}
\hline DCRPGDP & GDSGDP & PCONS & C \\
\hline 1.000000 & 0.000000 & $\begin{array}{l}-0.098594 \\
(0.01754)\end{array}$ & 24.57591 \\
0.000000 & 1.000000 & -0.107728 & 24.67147 \\
& & $(0.01070)$ & \\
Loglikelihood & -190.9306 & & \\
\hline
\end{tabular}




\subsection{Impulse response functions}

We analyse the impulse response function ${ }^{1}$ which traces the effect of a one standard deviation shock to one of the innovations on current and future values of the endogenous variables, namely DCRPGDP or M2GDP, GDSGDP and PCONS in this study. Figures 4 to 6 show the results of the impulse response analyses derived from the estimated VEC models. The number of lags used is 3 and based on the evidence provided by $\mathrm{L}=\mathrm{T}^{1 / 3}$ where $\mathrm{L}$ is number of lags and $\mathrm{T}$ is the number of data points used.

Figure 4 shows the response of PCONS to DCRPGDP. A shock to domestic credit to the private sector (DCRPGDP) reduces per capita consumption (PCONS) slightly in the first two periods and increased thereafter. However, the response to the shock by gross domestic savings (GDSGDP) is positive throughout the period.

Figure 5 also presents very straightforward results, as a DCRPGDP shock increases gross domestic savings throughout the entire period while a shock to per capita consumption increases slightly initially and dissipates thereafter.

In Figure 6, while a one time shock to gross domestic savings increases domestic credit to the private sector significantly, consumption shock reduces domestic private sector credit over the period. This is consistent with theory.

Figure 4

Impulse response to one SD innovation

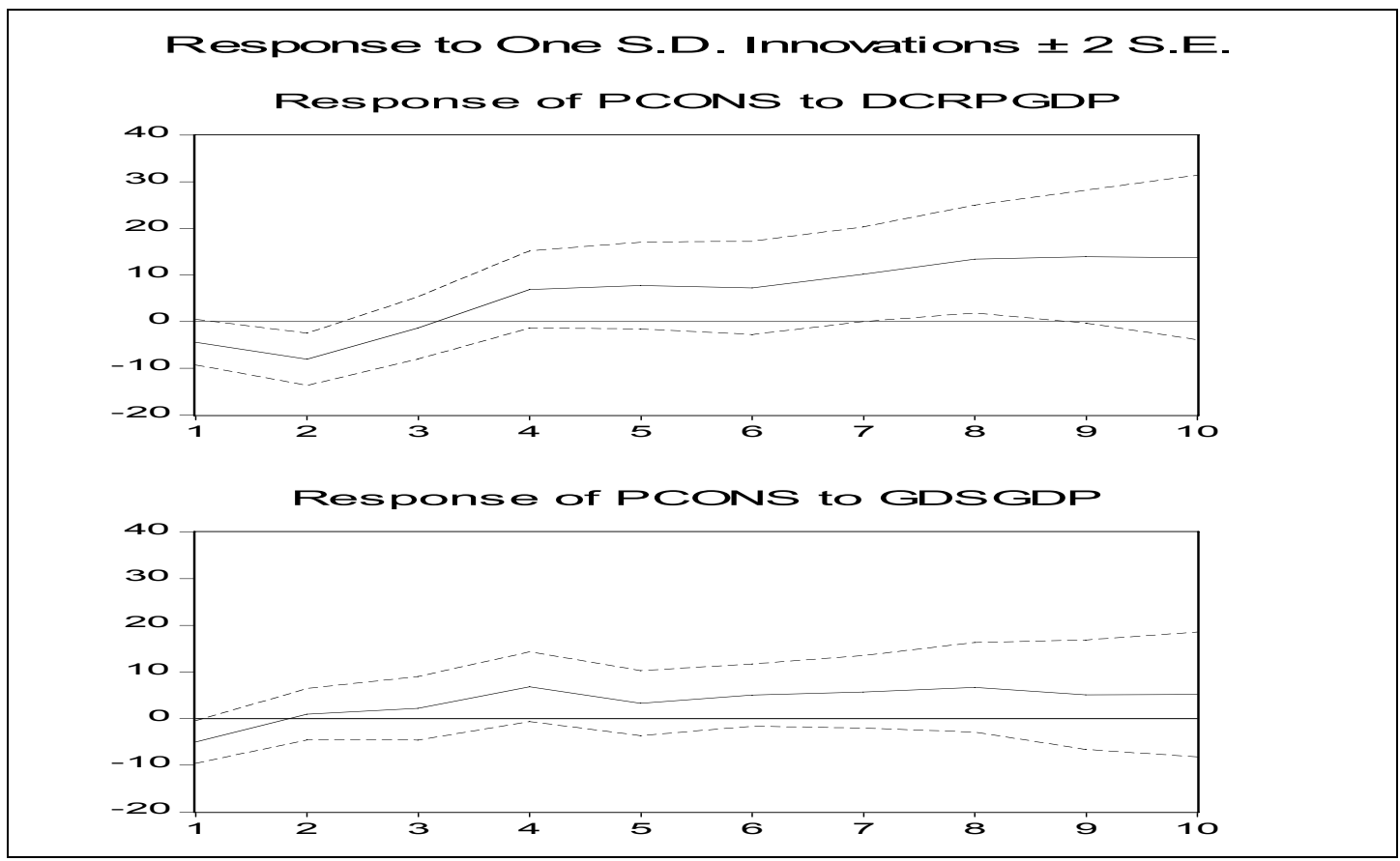

Source: World Bank (2004).

1 The non-linear responses of each variable to one-time shocks in the others traced over time. It facilitates an evaluation of the economic importance of the estimated effects. 
Figure 5

Impulse response to one SD innovation

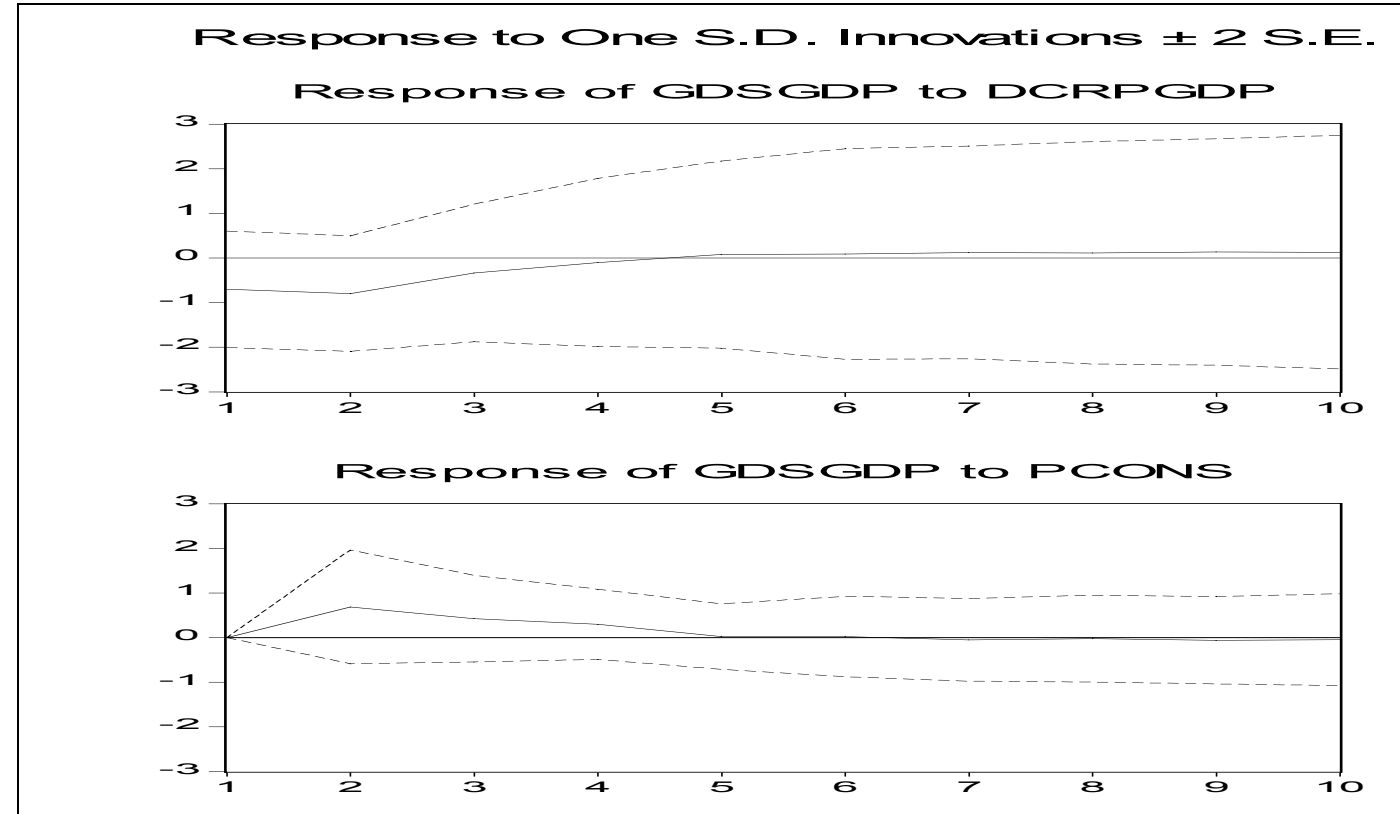

Source: World Bank (2004).

Figure 6

Impulse 5 response to one SD innovation

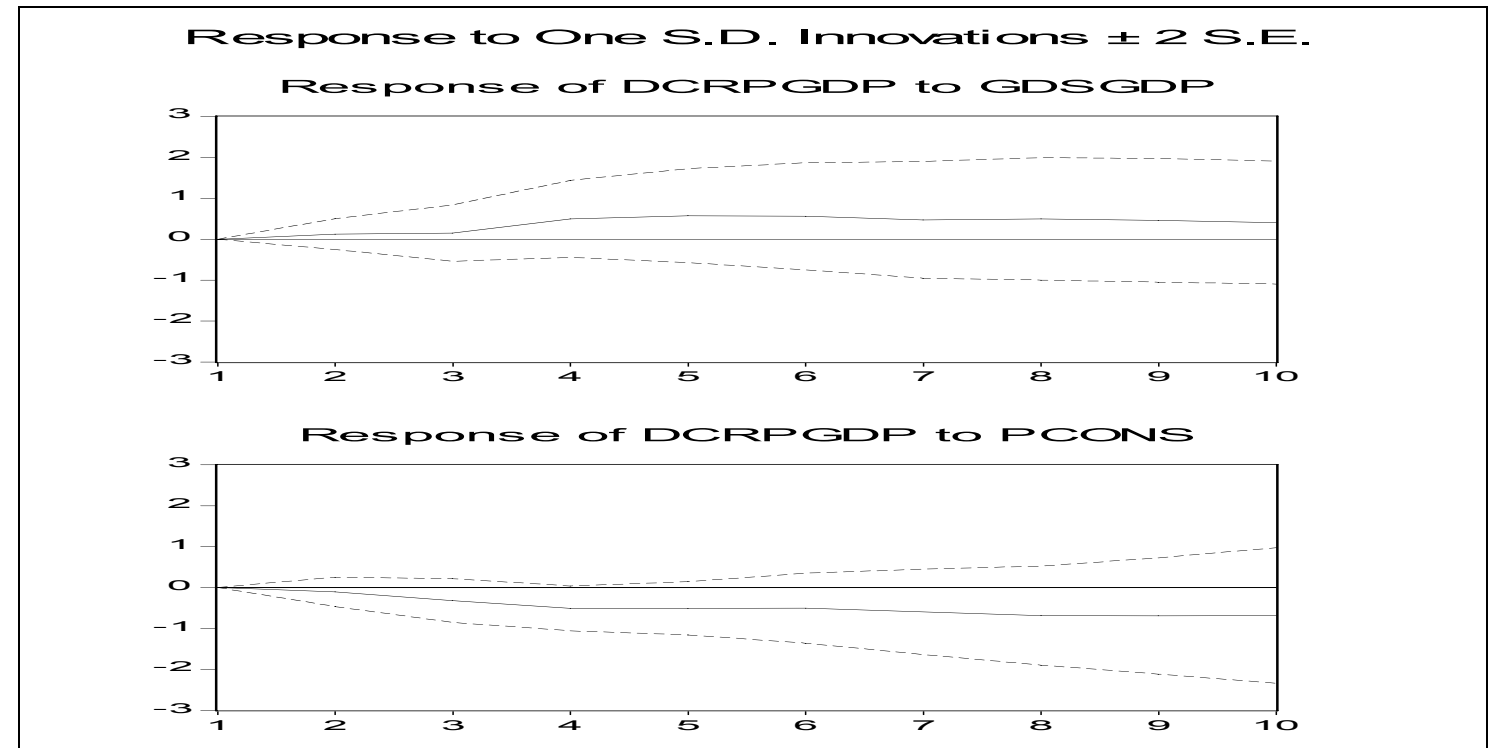

Source: World Bank (2004).

\subsection{Variance decomposition}

We proceed by analysing the variance decomposition. The variance decomposition shows the relative importance of shocks in explaining the deviations in an endogenous variable at different time horizons. Variance decomposition of domestic credit to the private sector (Table 9) shows that 54 per cent is explained by own innovations, 45 per 
cent by shocks in gross domestic savings to the private sector and about 1 per cent by shocks in per capita consumption.

For gross domestic savings to the private sector (Table 10), own innovations are dominant, as they explain 75 per cent, while domestic credit to the private sector and per capita consumption shocks account for 10 and 15 per cent, respectively.

Table 9

Variance decomposition of DCRPGDP

\begin{tabular}{ccccc}
\hline Period & S. E. & DCRPGDP & GDSGDP & PCONS \\
\hline 1 & 0.763334 & 100.0000 & 0.000000 & 0.000000 \\
2 & 1.176674 & 96.95336 & 2.897771 & 0.148869 \\
3 & 1.364637 & 95.20719 & 4.634740 & 0.158067 \\
4 & 1.718788 & 86.41760 & 13.12995 & 0.452453 \\
5 & 2.279829 & 69.95533 & 29.77262 & 0.272048 \\
6 & 2.832831 & 61.09347 & 38.44323 & 0.463302 \\
7 & 3.365944 & 55.77976 & 43.45032 & 0.769917 \\
8 & 3.717240 & 53.40766 & 45.27839 & 1.313943 \\
9 & 3.981644 & 53.59595 & 45.02523 & 1.378822 \\
10 & 4.214743 & 53.98803 & 44.71165 & 1.300310 \\
\hline
\end{tabular}

Table 10

Variance decomposition of GDSGDP

\begin{tabular}{ccccc}
\hline Period & S. E. & DCRPGDP & GDSGDP & PCONS \\
\hline 1 & 2.943256 & 5.619558 & 94.38044 & 0.000000 \\
2 & 3.717786 & 3.525251 & 79.92048 & 16.55427 \\
3 & 4.687001 & 10.20055 & 78.27052 & 11.52893 \\
4 & 5.075143 & 8.883154 & 74.00783 & 17.10901 \\
5 & 5.153183 & 10.23841 & 72.50481 & 17.25678 \\
6 & 5.359838 & 9.967505 & 73.67782 & 16.35467 \\
7 & 5.442229 & 9.745896 & 73.22124 & 17.03286 \\
8 & 5.885659 & 10.98832 & 74.30563 & 14.70605 \\
9 & 6.265994 & 9.820043 & 74.83177 & 15.34819 \\
10 & 6.593282 & 10.32316 & 74.74664 & 14.93020 \\
\hline
\end{tabular}

Table 11

Variance decomposition of PCONS

\begin{tabular}{ccccc}
\hline Period & S. E. & DCRPGDP & GDSGDP & PCONS \\
\hline 1 & 12.23237 & 26.07145 & 4.784787 & 69.14376 \\
2 & 16.64766 & 30.09125 & 20.52792 & 49.38083 \\
3 & 19.32105 & 24.07165 & 31.48910 & 44.43925 \\
4 & 24.55208 & 22.73100 & 48.12598 & 29.14302 \\
5 & 31.66148 & 15.02865 & 62.28263 & 22.68873 \\
6 & 36.38785 & 11.42264 & 64.42370 & 24.15366 \\
7 & 41.02324 & 9.272141 & 68.04194 & 22.68592 \\
8 & 44.17769 & 8.067642 & 68.73127 & 23.20108 \\
9 & 46.98156 & 8.001191 & 69.71971 & 22.27910 \\
10 & 49.99163 & 7.290224 & 70.86455 & 21.84522 \\
\hline
\end{tabular}


Table 12

Vector error correction model

\begin{tabular}{|c|c|c|c|c|}
\hline \multirow[b]{2}{*}{ Explanatory variables } & \multicolumn{4}{|c|}{ Dependent variables } \\
\hline & $\Delta$ PCONS $_{t}$ & $\Delta \mathrm{DCRPGDP}_{\mathrm{t}}$ & $\Delta G^{\prime} S G D P_{t}$ & $\Delta \mathrm{M}_{2} \mathrm{GDP}_{\mathrm{t}}$ \\
\hline ECM1 & $\begin{array}{c}-0.419582 \\
(-1.44744)\end{array}$ & $\begin{array}{l}-0.042361 \\
(-2.65925)\end{array}$ & $\begin{array}{c}0.022988 \\
(-0.46655)\end{array}$ & $\begin{array}{c}-0.06185 \\
(-1.86219)\end{array}$ \\
\hline ECM2 & $\begin{array}{r}1.507211 \\
(-0.62979)\end{array}$ & $\begin{array}{c}0.214065 \\
(-1.62772)\end{array}$ & $\begin{array}{c}0.645269 \\
(-1.58626)\end{array}$ & $\begin{array}{r}0.475427 \\
(-1.73382)\end{array}$ \\
\hline$\Delta$ PCONS $_{\mathrm{t}-1}$ & $\begin{array}{c}0.011679 \\
(-0.04474)\end{array}$ & $\begin{array}{c}0.024976 \\
(-1.74125)\end{array}$ & $\begin{array}{c}0.101754 \\
(-2.29343)\end{array}$ & $\begin{array}{c}0.022262 \\
(-0.74435)\end{array}$ \\
\hline$\Delta \mathrm{PCONS}_{\mathrm{t}-2}$ & $\begin{array}{c}-0.032568 \\
(-0.15704)\end{array}$ & $\begin{array}{l}0.011399 \\
-1.00025\end{array}$ & $\begin{array}{l}-0.042114 \\
(-1.19467)\end{array}$ & $\begin{array}{c}0.043581 \\
-1.83404\end{array}$ \\
\hline$\Delta \mathrm{PCONS}_{\mathrm{t}-3}$ & $\begin{array}{l}-0.392297 \\
(-1.71090)\end{array}$ & $\begin{array}{c}0.019591 \\
-1.55484\end{array}$ & $\begin{array}{c}-0.008713 \\
(-0.22356)\end{array}$ & $\begin{array}{l}0.036192 \\
-1.37758\end{array}$ \\
\hline$\Delta \mathrm{DCRPGDP}_{\mathrm{t}-1}$ & $\begin{array}{c}-7.310698 \\
(-1.32972)\end{array}$ & $\begin{array}{c}-0.203241 \\
(-0.67270)\end{array}$ & $\begin{array}{c}-0.973211 \\
(-1.04140)\end{array}$ & $\begin{array}{l}-0.7003 \\
(-1.11169)\end{array}$ \\
\hline$\Delta \mathrm{DCRPGDP} \mathrm{t}_{\mathrm{t}-2}$ & $\begin{array}{l}2.945863 \\
-0.58469\end{array}$ & $\begin{array}{l}-0.551346 \\
(-1.99138)\end{array}$ & $\begin{array}{l}0.500612 \\
-0.58456\end{array}$ & $\begin{array}{l}-0.939682 \\
(-1.62779)\end{array}$ \\
\hline$\Delta \mathrm{DCRPGDP}_{\mathrm{t}-3}$ & $\begin{array}{l}2.587089 \\
-0.56637\end{array}$ & $\begin{array}{l}-0.114388 \\
(-0.45570)\end{array}$ & $\begin{array}{c}-1.914735 \\
(-2.46609)\end{array}$ & $\begin{array}{l}-0.534344 \\
(-1.02096)\end{array}$ \\
\hline$\Delta \mathrm{GDSGDP}_{\mathrm{t}-1}$ & $\begin{array}{l}-3.636672 \\
(-1.46640)\end{array}$ & $\begin{array}{c}-0.35229 \\
(-2.58501)\end{array}$ & $\begin{array}{l}0.941766 \\
-2.23411\end{array}$ & $\begin{array}{c}-0.349282 \\
(-1.22921)\end{array}$ \\
\hline$\Delta \mathrm{GDSGDP}_{\mathrm{t}-2}$ & $\begin{array}{c}-2.80842 \\
(-1.26492)\end{array}$ & $\begin{array}{l}-0.374603 \\
(-3.07033)\end{array}$ & $\begin{array}{l}1.057838 \\
-2.80306\end{array}$ & $\begin{array}{l}-0.258439 \\
(-1.01592)\end{array}$ \\
\hline$\Delta \mathrm{GDSGDP}_{\mathrm{t}-3}$ & $\begin{array}{l}-2.491441 \\
(-1.41491)\end{array}$ & $\begin{array}{l}-0.205968 \\
(-2.12860)\end{array}$ & $\begin{array}{l}0.577137 \\
-1.92828\end{array}$ & $\begin{array}{c}-0.082809 \\
(-0.41045)\end{array}$ \\
\hline$\Delta \mathrm{M} 2 \mathrm{GDP}_{\mathrm{t}-1}$ & $\begin{array}{c}2.70431 \\
(-1.23725)\end{array}$ & $\begin{array}{l}-0.10246 \\
(-0.85304)\end{array}$ & $\begin{array}{c}0.63944 \\
(-1.72113)\end{array}$ & $\begin{array}{l}-0.291333 \\
(-1.16330)\end{array}$ \\
\hline$\Delta \mathrm{M} 2 \mathrm{GDP}_{\mathrm{t}-2}$ & $\begin{array}{r}1.923338 \\
(-1.00205)\end{array}$ & $\begin{array}{l}-0.085619 \\
(-0.81174)\end{array}$ & $\begin{array}{r}0.064504 \\
(-0.19771)\end{array}$ & $\begin{array}{l}-0.041355 \\
(-0.18805)\end{array}$ \\
\hline$\Delta \mathrm{M} 2 \mathrm{GDP}_{\mathrm{t}-3}$ & $\begin{array}{c}-2.002553 \\
(-1.06117)\end{array}$ & $\begin{array}{c}-0.057234 \\
(-0.55191)\end{array}$ & $\begin{array}{l}-0.003038 \\
(-0.00947)\end{array}$ & $\begin{array}{l}0.447299 \\
(-2.0687)\end{array}$ \\
\hline C & $\begin{array}{c}-5.200789 \\
(-1.42676)\end{array}$ & $\begin{array}{c}0.240924 \\
(-1.20275)\end{array}$ & $\begin{array}{r}0.104107 \\
(-0.16803)\end{array}$ & $\begin{array}{c}0.10384 \\
(-0.24863)\end{array}$ \\
\hline R-squared & 0.752236 & 0.668379 & 0.847315 & 0.607847 \\
\hline
\end{tabular}

Note: T-statistics in parentheses.

For per capita consumption (Table 11), gross domestic savings shocks are dominant in the system, accounting for 71 per cent of the innovations in per capita consumption. Own innovations contribute only 22 per cent, while domestic credit to the private sector explains 7 per cent. On the whole, per capita consumption is a variable that is weak in accounting for its own innovations and that of other variables.

Finally, as can be seen from Table 12, an increase in credit to the private sector has a positive but insignificant effect on poverty in the country while a decrease in poverty levels has an insignificant effect on poverty. From column 3 it can be seen that a 
decrease in poverty levels leads to a significant improvement in gross domestic savings. Also, an increase in credit to the private sector reduces gross domestic savings.

In trying to establish the relationship of the effect of financial development on poverty in Ghana, we modelled per capita consumption as our household welfare indicator (dependent variable). Table 12 presents the parameter estimates of four regressions. The fit is good in all the four regressions. The $\mathrm{R}^{2}$ values show that a large proportion of the variations in per capita consumption is explained by the variations in the explanatory variables in the model. From Table 12 an increase in credit to the private sector has a positive but insignificant effect on poverty in Ghana. Also, from column 3, a decrease in poverty levels will lead to a significant improvement in gross domestic savings. Furthermore, an increase in credit to the private sector will reduce gross domestic savings.

\subsection{Financing the pro-poor sectors of the economy}

The empirical evidence above suggests that financial sector development Grangercauses poverty reduction in Ghana. Furthermore, the impact of financial sector development on poverty is positive but insignificant, implying that financial sector development leads to poverty reduction if the financial intermediaries in Ghana allocate considerable proportions of their loan portfolio to those sectors of the economy that have strong links to poverty reduction. Increased credit to the private sector (an important indicator of financial sector development) can lead to poverty reduction, particularly when credit is intermediated to the pro-poor sectors of the economy, mainly, agriculture 2 and industry. The Ghana Living Standards Survey indicates that the poor are mostly employed within the agricultural sector and are mostly foodcrop farmers. Furthermore, agriculture employs about 55 per cent of the population and contributes about 40 per cent to GDP in Ghana. Therefore, increased credit to the agricultural sector as well as manufacturing can significantly reduce poverty.

In order to ascertain whether financial sector development in Ghana has actually affected the pro-poor sectors of the economy, we examine the proportion of domestic credit to the various sectors of the economy. From Table 13, it can be noted that total domestic credit increased from Cedis 1,416 billion in 1995 to Cedis 6,354 billion in 1999 and then to Cedis 15,626 billion in 2003. Another notable finding is that there has been a decline in the share of domestic credit to the central government (decreasing from 59.0 per cent in 1995 to 45.6 per cent in 2002 to 32.5 per cent in 2003) while the shares of total domestic credit to public and private enterprises increased from 8.3 per cent to 14.2 per cent over the same period. Similarly, the share of domestic credit to the private sector increased from 46.1 per cent to 53.3 per cent over the same period; an increase of about 7.2 percentage points (Table 13). It can be argued that credit to private enterprises dominates the proportion of domestic credit to the three economic categories in 2003. This is a positive signal and more of similar policies should be pursued to stimulate private sector growth. Government over the years has crowded-out the private sector in terms of credit allocation and this has not encouraged the private investment needed to achieve sustained economic growth.

2 Agriculture accounts for about 40 per cent of GDP and employs 55 per cent of the labourforce according to GLSS 4. 
Viewed in terms of the allocation of credit to the various economic sectors of the country, the share of DMB credit to agriculture, one of the major drivers of growth and poverty reduction, declined consistently between 1999 and 2003. Similarly, the share of domestic credit to manufacturing declined between 2000-03. Likewise, the share of domestic credit to all the other sectors has declined over the past 4-5 years except for the category identified as 'others', comprising electricity, gas and water, import, export, and domestic trade, transport, storage and communications, services and cocoa marketing (Table 14).

The decline in the share of DMB credit to manufacturing, mining and construction and also the zero change in the share of credit to agriculture raise certain issues for policy consideration. First, it questions the current effort of reducing poverty, given the marginal or zero change in credit to the agricultural sector, one of the key engines of growth.

Table 13

Distribution of domestic credit, 1995-2003

\begin{tabular}{|c|c|c|c|c|c|c|c|}
\hline \multirow[b]{2}{*}{ Year } & \multicolumn{2}{|c|}{ Central government } & \multicolumn{2}{|c|}{ Public enterprises } & \multicolumn{2}{|c|}{ Private enterprises } & \multirow{2}{*}{$\frac{\text { Total }}{\text { Cedis bn }}$} \\
\hline & Cedis bn & $\%$ & Cedis bn & $\%$ & Cedis bn & $\%$ & \\
\hline 1995 & 835.0 & 59.0 & 188.0 & 13.3 & 393.0 & 27.8 & $1,416.0$ \\
\hline 1996 & 107.0 & 10.8 & 200.0 & 20.3 & 680.0 & 68.9 & 987.0 \\
\hline 1997 & 777.0 & 39.3 & 128.0 & 6.5 & $1,070.0$ & 54.2 & $1,975.0$ \\
\hline 1998 & $2,420.0$ & 56.9 & 194.0 & 4.6 & $1,639.0$ & 38.5 & $4,253.0$ \\
\hline 1999 & $3,464.0$ & 54.5 & 424.0 & 6.7 & $2,466.0$ & 38.8 & $6,354.0$ \\
\hline 2000 & $5,839.0$ & 53.7 & $1,213.0$ & 11.2 & $3,826.0$ & 35.2 & $10,878.0$ \\
\hline 2001 & $5,989.0$ & 49.0 & $1,762.0$ & 14.4 & $4,472.0$ & 36.6 & $12,223.0$ \\
\hline 2002 & $5,797.0$ & 45.6 & $1,050.0$ & 8.3 & $5,864.0$ & 46.1 & $12,711.0$ \\
\hline 2003 & $5,084.6$ & 32.5 & $2,212.3$ & 14.2 & $8,328.7$ & 53.3 & $15,626.0$ \\
\hline 2003, Q1 & $6,146.8$ & 47.2 & $1,091.0$ & 8.4 & $5,786.2$ & 44.4 & $13,024.0$ \\
\hline 2003, Q2 & $5,557.8$ & 41.9 & $1,314.2$ & 9.9 & $6,403.5$ & 48.2 & $13,276.0$ \\
\hline 2003, Q3 & $5,257.8$ & 36.9 & 693.2 & 4.9 & $8,312.9$ & 58.3 & $14,264.0$ \\
\hline 2003, Q4 & $5,084.6$ & 32.54 & $2,212.3$ & 14.2 & $8,328.7$ & 53.3 & $15,626.0$ \\
\hline
\end{tabular}

Source: Bank of Ghana (various years)

Table 14

Sectoral allocation of credit by DMBs, 1995-2003

\begin{tabular}{lcccccc}
\hline Year & Agriculture & Manufacturing & Mining & Construction & Others & Total \\
\hline 1995 & 9.7 & 29.8 & 1.5 & 11.7 & 47.3 & 100 \\
1996 & 10.8 & 31.0 & 4.0 & 9.8 & 44.4 & 100 \\
1997 & 12.0 & 22.8 & 5.1 & 10.1 & 50.0 & 100 \\
1998 & 12.2 & 24.6 & 5.0 & 11.2 & 47.0 & 100 \\
1999 & 11.8 & 24.9 & 5.8 & 8.9 & 48.6 & 100 \\
2000 & 9.6 & 28.1 & 5.5 & 6.8 & 60.3 & 100 \\
2001 & 9.6 & 19.3 & 4.0 & 6.8 & 60.3 & 100 \\
2002 & 9.4 & 21.1 & 3.7 & 7.8 & 58.0 & 100 \\
2003 & 9.4 & 20.7 & 2.9 & 5.0 & 62.0 & 100 \\
\hline
\end{tabular}

Source: ISSER (2004). 
Second, the share of domestic credit to the industrial sector has been dwindling, implying that the concept of promoting industrialization and achieving a golden age of business in Ghana remains fuzzy. Ironically, the 'others' category took a significant proportion of DMB credit but this category is not the principal sector for poverty reduction. Thus to re-emphasize the point, credit to the pro-poor sector in Ghana has not increased to ensure poverty reduction. The reasons for this are varied, but one of the main factors has been the financing of government budget deficit through borrowing from the domestic banking system.

Government borrowing has been handled through the sale of treasury bills at interest rates ranging between 26-40 per cent. Ghanaian financial institutions prefer to lend to the government than to the private sector, as treasury bills are considered very attractive and less risky. Borrowers, on the other hand, particularly those engaged in agricultural and manufacturing, find the cost of loans too expensive and cannot break even after their operating costs have been met. A related issue is the high default rate of loans, due partly to the lack of information on borrowers as well as the high interest rates. Another major factor explaining the low level of credit to the pro-poor sectors of the economy is the lack of 'bankable' projects or proper business plans. Furthermore, the absence of a well-developed insurance market means that banks require borrowers to provide collateral security as a guarantee against future default. Unfortunately, the lack of proper title to land in Ghana has disqualified many people engaged in agriculture from accessing loans. As can be noted from the foregoing, although financial sector development can cause poverty reduction, this has not been the case in Ghana.

\section{Conclusion and policy implications}

This paper sought to investigate the interrelationship between financial sector development, savings mobilization and poverty reduction in Ghana. The theoretical basis is that if financial sector development causes savings mobilization and savings causes poverty reduction, then by intuition, a developed financial market will promote poverty reduction. In order to empirically investigate this relationship, the paper used annual data from 1970 to 2001 to ascertain the causal relationship between these variables and made very interesting findings. First, it found that although financial sector development does not Granger-cause savings mobilization in Ghana, financial sector development causes poverty reduction. Second, the effect of financial development on poverty in Ghana is positive but insignificant. This is because financial intermediaries in Ghana have not adequately channelled savings to the pro-poor sectors of the economy and the major reasons have been the government deficit financing, high default rate, lack of collateral and lack of proper business proposals. Another interesting finding is that there is a long-run cointegration relationship between financial sector development and poverty reduction.

On the basis of the above findings, the paper suggests some key issues for policy consideration. First, the interest rate margin between lending and borrowing rates is too high to stimulate domestic savings in Ghana. Thus, the central bank in collaboration with the financial institutions should ensure that holders of savings accounts receive realistic interest rates. A related suggestion is that government borrowing through the sale of treasury bills should be minimized since it has not encouraged financial institutions to mobilize savings and on-lending to private investors. The study also notes 
that in Ghana financial sector development promotes poverty reduction. This implies that even though the country's financial sector has not adequately mobilized domestic savings, they have affected poverty through investments in short- and long-term equity. Thus, the government could further stimulate the work of these intermediaries by offering tax concessions or reductions to the financial institutions who invest in the propoor sectors of the economy, particularly in the agricultural sector. Finally, the high interest rate margin between lending and borrowing rates offered to the private sector has been attributed to the high level of loan defaults. The study believes that the default rate could be minimized by using the services of credit reference agencies and of insurance companies. In the case of the former, they could provide credit checks on potential borrowers to minimize the risk of lending to less creditworthy entrepreneurs. Insurance companies could also provide cover on loans made to private investors. These two channels have not been explored in Ghana and the paper suggests that the provision of such services be expedited. 
Appendix Figure 1

Graphs in levels
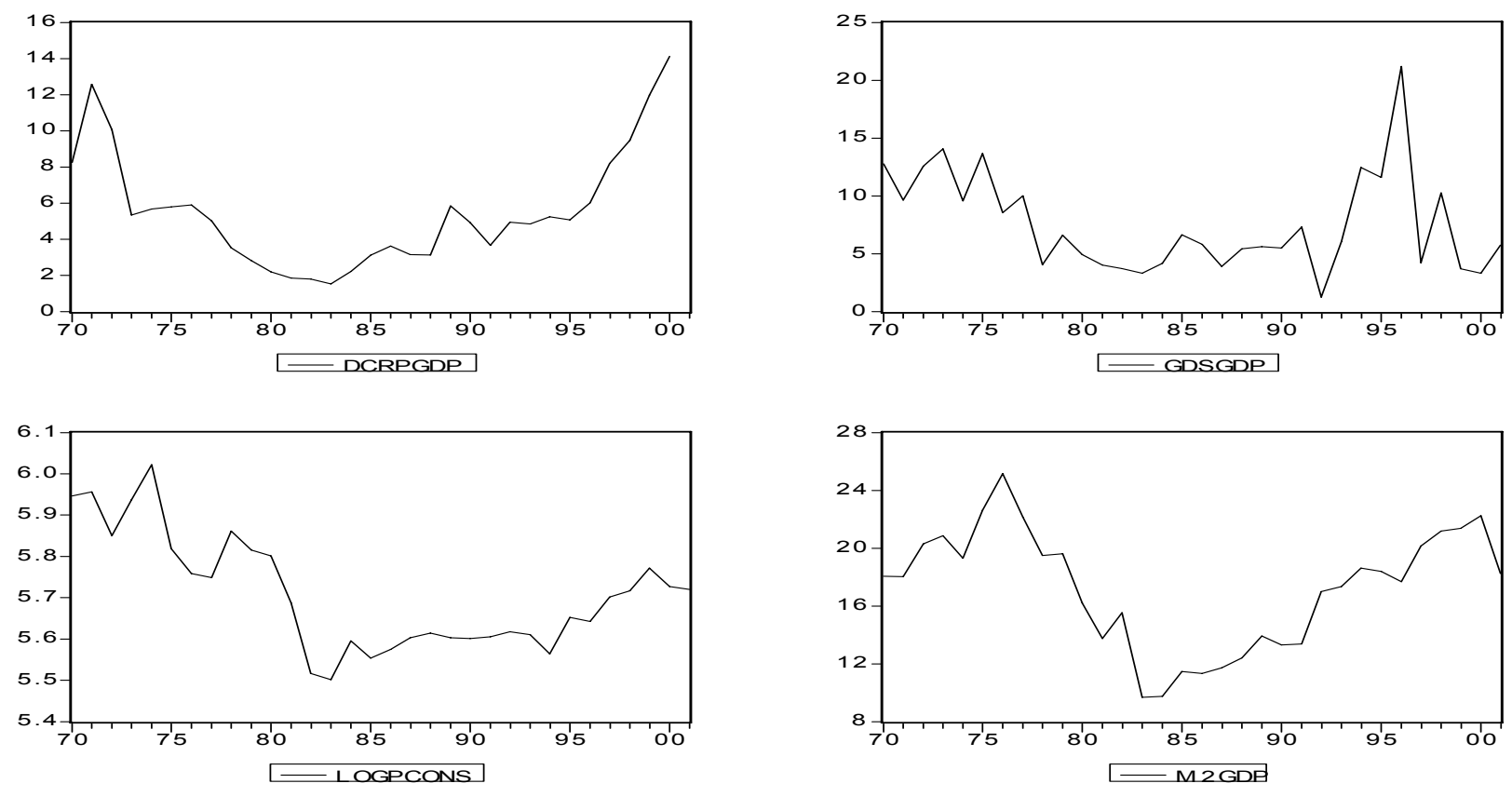

Source:

World Bank (2004). 
Appendix Figure 2

Graphs after first difference
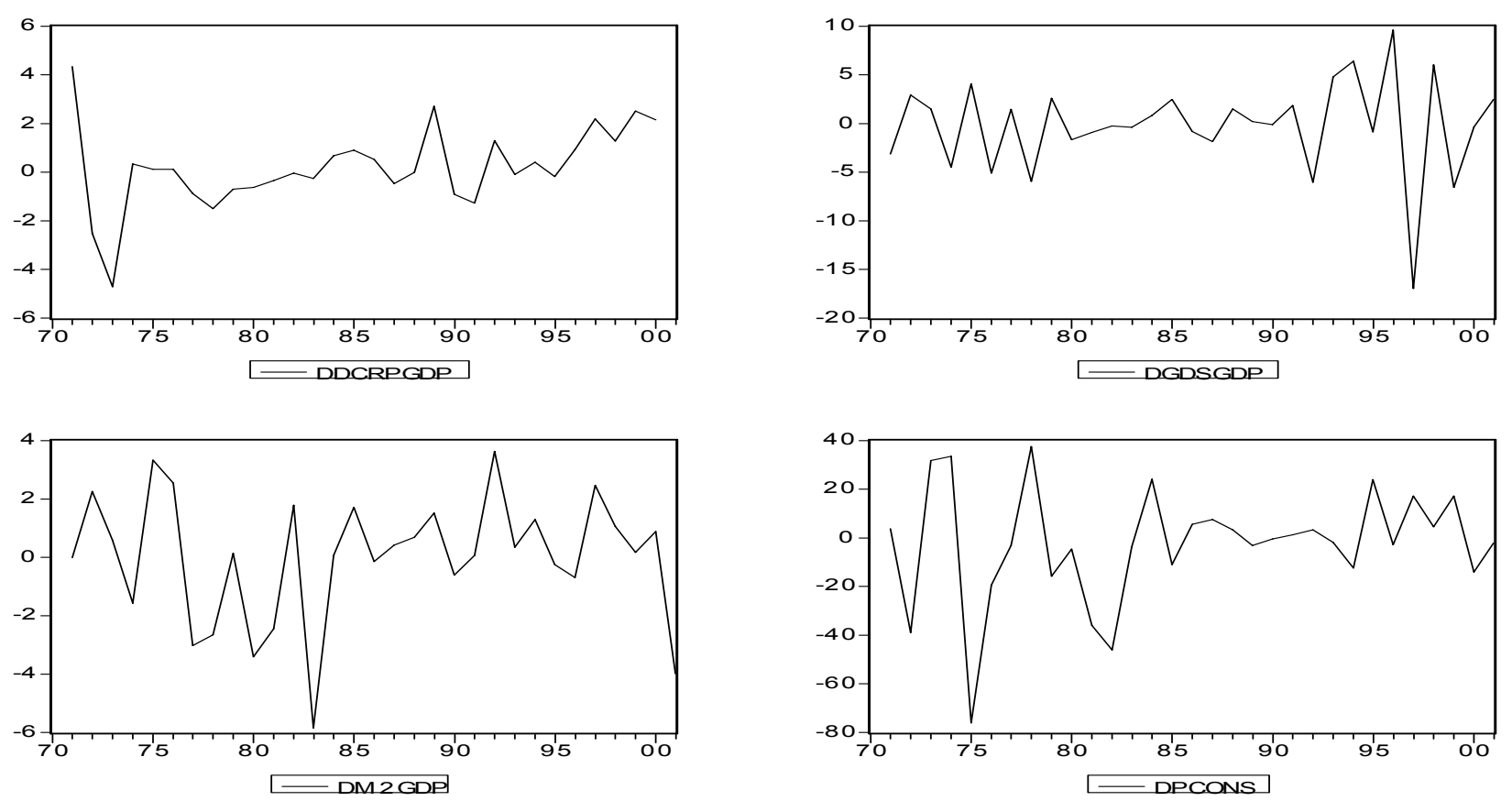

Source: $\quad$ World Bank (2004). 


\section{References}

Anoruo, E., and Y. Ahmad (2001). 'Causal Relationship between Domestic Savings and Economic Growth: Evidence from Seven African Countries’. African Development Review, 13 (2): 238-49.

Aryeetey, E. (2005). 'The Role of the Financial Sector in Securing Pro-Poor Growth in Sub-Saharan Africa’. AERC Senior Policy Paper No. 7. Nairobi: African Economic Research Consortium.

Bacchetta, P., and S. Gerlach (1997). 'Consumption and Credit Constraints: International Evidence’. Journal of Monetary Economics, 40 (2): 207-38.

Bandiera, O., G. Caprio, P. Honohan, and F. Schiantarelli (1998). 'Does Financial Reform Raise or Reduce Savings?’. Boston College Working Papers in Economics 413. Boston: Boston College Department of Economics.

Bandiera, O., G. Caprio, P. Honohan, and F. Schiantarelli (2000). 'Does Financial Reform Raise or Reduce Saving?'. Review of Economics and Statistics, 82 (2): 239-63.

Banerjee, A. V., and A. Newman (1993). 'Occupational Choice and the Process of Development'. Journal of Political Economy, 101 (2): 274-98.

Bank of Ghana Statistical Bulletins (various issues). Accra: Bank of Ghana.

Beck, T., A. Demirgüç-Kunt, and R. Levine (2004). 'Finance, Inequality, and Poverty: Cross-Country Evidence’. Policy Research Working Paper Series 3338. Washington, DC: World Bank.

Benhabib, J., and B. Jovanovic (1991). 'Externalities and Growth Accounting'. American Economic Review, 81 (1): 82-113.

Blomstrom, M., R. Lipsey, and M. Zejan (1996). 'Is Fixed Investment the Key to Economic Growth?’ Quarterly Journal of Economics, 111 (1): 269-76.

Campbell, J. Y., and G. Mankiw (1989). 'International Evidence on the Persistence of Economic Fluctuations’. NBER Working Papers 2498. Cambridge, MA: National Bureau of Economic Research.

Campbell, Y., and N. Mankiw (1990). 'Permanent Income, Current Income and Consumption’. Journal of Business and Economic Statistics, 8 (3): 265-79.

Cardenas, M., and A. Escobar (1998). 'Saving Determinants in Colombia: 1925-1994'. Journal of Development Economics, 57: 5-44.

Clarke, G., L. Xu, and H-.F. Fou (2002). 'Finance and Income Inequality: Test of Alternative Theories’. Policy Research Working Paper Series 2984. Washington, DC: World Bank.

de Brouwer, G. (1996). 'Consumption and Liquidity Constraints in Australia and East Asia: Does Financial Integration Matter?’. RBA Research Discussion Papers rdp9602. Sydney: Reserve Bank of Australia.

de Melo, J., and J. Tybout (1986). 'The Effects of Financial Liberalization on Savings and Investment in Uruguay'. Economic Development and Cultural Change, 34 (3): 561-87. 
Deininger, K., and L. Squire (1996). 'A New Data Set for Measuring Income Inequality’. World Bank Economic Review, 10: 565-91.

Demetriades, P. O., and K. A. Hussein (1996). 'Does Financial Development Cause Economic Growth? Time-series Evidence from 16 Countries'. Journal of Development Economics, 51 (2): 387-411.

Dollar, D., and A. Kraay (2001). 'Growth Is Good for the Poor'. Policy Research Working Paper Series 2587. Washington, DC: World Bank

Edwards, S. (1996). 'Why Are Latin America’s Savings Rates so Low? An International Comparative Analysis'. Journal of Development Economics, 51 (1): 5-44.

Galor, O., and J. Zeira (1993). 'Income Distribution and Macroeconomics'. Review of Economic Studies, 60: 35-52.

Ghana Statistical Service (2000). Poverty Trends in Ghana in the 1990s. Accra: Ghana Statistical Service.

Ghana Statistical Service (2003). 'Ghana Statistical Service Core Welfare Indicator Questionnaire, CWIQ, 2003’. Accra: Ghana Statistical Service.

GLSS (various yeas). 'Ghana Living Standards Survey, Waves 3 and 4'. Accra: Ghana Statistical Service.

Goudie, A., and P. Ladd (1999). 'Economic Growth, Poverty and Inequality'. Journal of International Development, 11 (2): 177-95.

Government of Ghana (GoG) (2003). 'Ghana Poverty Reduction Strategy 2003-2005: An Agenda for Growth and Prosperity’ (a simplified version). August. Accra: Government of Ghana.

Greenwood, J., and B. Jovanovich (1990). 'Financial Development, Growth, and. the Distribution of Income’. Journal of Political Economy, 98 (5): 1076-107.

Hall, R. H. (1978). 'The Stochastic Implications of the Life Cycle-Permanent Income Hypothesis: Theory and Evidence'. Journal of Political Economy, 86 (6): 971-87.

Honohan, P. (2004). 'Financial Development, Growth and Poverty: How Close Are the Links?', in C. Goodhart (ed.), Financial Development and Economic Growth: Explaining the Links. Basingstoke: Palgrave Macmillan.

ISSER (Institute of Statistical, Social and Economic Research) (2004). 'The State of the Ghanaian Economy in 2003’. Legon: ISSER.

Jalilian, H., and C. Kirkpatrick (2001). 'Financial Development and Poverty Reduction in Developing Countries'. Working Paper No. 30. Manchester: Institute for Development Policy and Management, University of Manchester.

Jappelli, T., and M. Pagano (1994). 'Saving, Growth and Liquidity Constraints'. Quarterly Journal of Economics, 109 (1): 83-109.

Johansen, S (1991). 'Estimation and Hypothesis Testing of Cointegration Vectors in Gaussian Vector Autoregressive Models’. Econometrica, 59 (6): 1551-80.

Johansen, S. (1988). 'Statistical Analysis of Cointegrating Vectors'. Journal of Economics Dynamics and Control, 12: 231-54. 
Johansen, S. (1992). 'Cointegration in Partial Systems and the Efficiency of SingleEquation Analysis’. Journal of Econometrics, 52 (3): 389-402.

Johansen, S., and K. Juselius (1990). 'Maximum Likelihood Estimation and Inference on Cointegration-with Applications to the Demand for Money'. Bulletin of Economics and Statistics, 52 (2): 169-210.

Jung, W. J. (1986). 'Financial Development and Economic Growth: International Evidence’. Economic Development and Cultural Change, 34 (January): 333-46.

Kelly, R., and G. Mavrotas (2003). 'Savings and Financial Sector Development: Panel Cointegration Evidence from Africa'. WIDER Discussion Paper No. 2003/12. Helsinki: UNU-WIDER.

King, M. (1986). 'Capital Market “Imperfections” and the Consumption Function', Scandinavian Journal of Economics, 88 (1): 59-80.

King, R. G., and R. Levine (1994). 'Capital Fundamentalism, Economic Development, and Economic Growth'. Carnegie-Rochester Conference Series on Public Policy 40 (June): 259-92.

Ludvigson, S. (1996). 'The Macroeconomic Effects of Government Debt in a Stochastic Growth Model'. Journal of Monetary Economics, 38 (1): 25-45.

Mavrotas, G., and M. Santillana (1999). 'Savings and Financial Sector Development: Key Issues'. Paper presented at the International Conference on Finance and Development, 9-10 July. Manchester.

Mavrotas, G., and R. Kelly (2001). 'Savings Mobilization and Financial Sector Development: The Nexus’. Savings and Development, 25 (1): 33-66.

McKay, A. (2002). 'Economic Growth and Distribution of Poverty in Developing Countries', in C. Kirkpatrick, R. Clarke, and C. Polidano (eds), Handbook on Development Policy and Management. Cheltenham: Edward Elgar.

McKinnon, R. I. (ed.) (1973). Money and Capital in Economic Development. Washington, DC: Brookings Institution Press.

Muellbauer, J., and A. Murphy (1993). 'Income Expectations, Wealth and Demography in the Aggregate UK Function'. Paper presented at the HM Treasury Academic Panel, London.

Ostry, J. D., and J. Levy (1995). 'Household Saving in France: Stochastic Income and Financial Deregulation’. IMF Staff Papers 42. Washington, DC: IMF.

Quartey, P. (1997). 'The Effect of Non-bank Financial Intermediaries on Monetary Policy in Ghana’. Ghana: University of Ghana. Mimeo.

Ravallion, M. (2001). 'Growth, Inequality and Poverty: Looking beyond Averages'. World Development, 29 (11): 1803-15.

Shaw, E. (1973). Financial Deepening in Economic Development. New York: Oxford University Press.

Squire, L. (1999). 'The Evolution of Thinking about Poverty: Exploring the Interaction'. Ninth Bradford Development Lecture, DPPC. Bradford: University of Bradford. 
Toda, H. Y., and T. Yamamoto (1995). 'Statistical Inference in Vector Autoregressions with Possibly Integrated Processes’. Journal of Econometrics, 66 (1-2): 225-50.

Wachtel, P., and P. Rousseau (1995). 'Financial Intermediation and Economic Growth: A Historical Comparison of the United States, United Kingdom and Canada', in M. Bordo and R. Sylla (eds), Anglo-American Financial Systems: Financial Institutions and Markets in the Twentieth Century. Burr Ridge, IL: Irwin.

World Bank (2001). World Development Report 2000/2001. New York: Oxford University Press

World Bank (2003, 2004). World Development Indicators, 2003; World Development Indicators, 2004. Washington, DC: World Bank. 